\title{
AIR CARGO DEVELOPMENT IN THE REGIONAL AIRPORTS OF THE BALTIC SEA REGION THROUGH ROAD FEEDER SERVICES
}

\author{
Anatoli Beifert \\ Wismar University of Applied Sciences \\ Philipp-Müller Str. 14, 23966 Wismar, Germany \\ E-mail: anatoli.beifert@hs-wismar.de
}

\begin{abstract}
As issued in the Competition Policy Brief on the new state aid rules for a competitive aviation industry by the Competition Directorate-General of the European Commission in February 2014 ${ }^{1}$, it will be more difficult for unprofitable airports, to obtain financial public subsidies on EU, national or regional level. Although the positive impact of small airports on the regional development and general accessibility was mentioned, still the operating aid to the airports shall be cut out over a maximum of 10 years. It has been further stated that the vast majority of small and regional airports experience problems to cover their running operative costs, as a result from an intensive market competition and overlapping of airports' catchment areas preventing even some promising airports from growth. Public subsidies are mostly used by the airport management for infrastructural investments, to cover operating losses or to attract price-sensitive airlines. Herewith, among other things, the EU Commission is pointing out at the lack of cooperation structures and network strategies among the regional airports and at rather isolated and individual approach during elaboration of the airport development scenarios. However, the Competition Policy Brief permits public aid to regional airports, among other things if there is sufficient transports need to establish transition periods for small airports; the need for more flexibility of the regional airports in the remote areas has been underlined. The EU Commission is expecting herewith not to close the regional airports, but to stimulate them to operate on cost efficient and profitable basis, and that only the most inefficient airports will be closed.

To cope with the upcoming challenges the regional airports are demanded now to revaluate and reconsider their future development plans. While focusing on the passenger traffic many regional airports ignore or underestimate the benefits of the airfreight market. Although the air cargo has rather a low volume, but very high revenue yield part. Business internationalization is one of the important driving forces for the airfreight nowadays as well as decreasing air transport costs due to improving efficiency and growing competition among the air carriers. Most regional airports in the Baltic Sea region that act totally isolated, do not have a clear picture of the current situation on the international air cargo market, its future perspectives and sustainable development plans. Trying to meet the market demand, the regional airports are making huge and unjustified investments, e.g. improving airport infrastructure. It is not clear till now which elements of the Pan-Baltic cargo market could be managed as an alternative revenue yielding services for consolidated operation by air or what infrastructure is needed to provide the opportunity for an optimal economic mix of road-rail-air-sea transport? Nowadays, to a large degree air cargo traffic relies on scheduled, frequent passenger services in hub-and-spoke as well as in point-to-point traffic. Regional airports are presently suffering from a lack of scheduled uplift capacity. The volume currently transported by air in the regional airports is almost entirely based on the occasional charter flights. However, the growth of the air cargo business is likely to be based not only on cargo charters, but to a larger extend on truck-based services for transit shipments. Onward transportation by truck may occur on road feeder service, so called "flying trucks", where a real truck substitutes a flight. "Flying trucks" are having flight numbers etc., therefore they must be prioritized in many ways in the BSR transport policy.

This paper investigates the role of Road Feeder Services concept (thereafter named here as "Flying Truck") as an optional freight value proposition for the development of the regional airports and their possible participation in the air cargo market as a supplement instrument to generate additional revenue, thus making the airports more profitable and attractive.
\end{abstract}

Keywords: Air cargo, Road Feeder Services (RFS), regional airports, multimodality, air-road concept

\section{Introduction and Problem Definition}

Aviation plays an essential role in the European economic development for both citizens and industry. With a network of more than 440 airports, and more than 60 air navigation service providers, the European aviation industry carries about $40 \%$ of Europe's exports and imports value, and transports over 822 million passengers annually to and from Europe. Although the major part of these activities belongs rather to bigger aviation hubs, the availability of the current regional airports' infrastructure has also a wide range impact on economic activities, enhancing business internationalization, improving regional accessibility, attracting investments and boosting job growth. Playing a role of an economic gravity in a region, the regional airports stimulate business economic competitiveness of the region.

\footnotetext{
${ }^{1}$ Cf. Competition Policy Brief on the New State aid rules for a competitive aviation industry, Competition Directorate-General of
} the European Commission, February 2014, ISBN 978-92-79-35541-7 
With regard to the specific air cargo market in the Baltic Sea Region (hereafter: BSR) the current results presented in this paper to a large extend are based on the reports and official outputs produced in the framework of the EU funded research project "Baltic.AirCargo.Net" (http://www.balticaircargo.net/) ${ }^{2}$.

In order to define the region in the following study, the dimensions of the BSR has been set by the coordinates of the airports Cologne (CGN) for the western and Hahn (HHN) for the Southern boundary in Germany; Mehamn airport (MEH) in Norway sets the Northern and airport Ivanovo (IWA) I Russia defines the Eastern boundary of the BSR (Table 1).

Table 1. Defining BSR airports (FlightStats 2013) $)^{3}$

\begin{tabular}{|c|c|c|c|c|c|c|}
\hline City & Airport Name & IATA Code & ICAO Code & Longitude & Latitude & Country \\
\hline Mehamn & Mehamn & MEH & ENMR & 71.03333 & 27.833332 & Norway \\
\hline Hahn & Frankfurt - Hahn & HHN & EDFH & 49.948334 & 7.264167 & Germany \\
\hline Cologne & Cologne Bonn & CGN & EDDK & 50.878365 & 7.122224 & Germany \\
\hline Ivanovo & Ivanovo & IWA & & 56.942955 & 40.944546 & Russia \\
\hline
\end{tabular}

According to these set frames, there are 290 civil airports in the BSR (i.e. having a 3-letter IATA code) of which 176 airports $(61 \%)$ have regular scheduled traffic (Table 2$){ }^{4}$

Table 2. BSR Airports (OAG, Flightstats)

\begin{tabular}{|l|c|c|}
\hline \multicolumn{1}{|c|}{ Countries } & Number of Airports in the Region ${ }^{\mathbf{1}}$ & $\begin{array}{c}\text { Number of Airports with scheduled } \\
\text { Traffic }^{\mathbf{2}}\end{array}$ \\
\hline Belarus & 7 & 1 \\
\hline Denmark & 18 & 9 \\
\hline Estonia & 6 & 4 \\
\hline Finland & 31 & 22 \\
\hline Germany & 66 & 23 \\
\hline Latvia & 3 & 1 \\
\hline Lithuania & 6 & 4 \\
\hline Norway & 46 & 41 \\
\hline Poland & 18 & 12 \\
\hline Russia & 33 & 18 \\
\hline Sweden & 56 & 41 \\
\hline Sum & $\mathbf{2 9 0}$ & $\mathbf{1 7 6}$ \\
\hline
\end{tabular}

(1) Airports with IATA Code located within the region defined above (cf. Table 1)

(2) Recorded Traffic in 2013

The Baltic states, i.e. Estonia, Latvia, Lithuania and Belarus have 22 airports in total of which ten (four, one, four and one respectively) have regular scheduled traffic. Despite strong competition from Germany, Sweden and Norway the main hub of Denmark - Copenhagen airport (CPH) has a large share of cargo traffic and ranks seventh in terms of number of cargo flights, behind German airports Frankfurt international (FRA; 1.), Frankfurt-Hahn (HHN; 3.), Halle/Leipzig (LEJ; 4.) and Köln/Bonn (CGN; 6.) and the Russian airports SVO (2.) and DME (5.).

It may be also sated that the airports in the BSR are located close to each other with the overlapping catchment areas and close distances to the bigger hubs. Thus the regional airports need to seek a comparative advantage over other airports and countries.

\footnotetext{
${ }^{2}$ Baltic Sea Region Programme 2007 - 2013, ERDF Funds

${ }^{3}$ Cf. Bubalo, Branko, Economic Outlook for an Air Cargo market in the Baltic Sea region, Baltic.AirCargo.Net Project, 2013

${ }^{4}$ Regular scheduled traffic here - minimum one flight observation per week in 2013, FlightStats.
} 
Figure 1 demonstrates the distribution of the air cargo flights in the BSR of the observations in the 2013. About half of all cargo flights (47\%) go through Frankfurt am Main International airport (FRA), ca. $22 \%$ of the flights pass Moscow-Sheremetyevo (SVO) airport. The main air cargo market players in the BSR are Germany with a total market share of 59\% (Frankfurt [FRA], Frankfurt-Hahn [HHN], Halle/Leipzig [LEJ] and Köln/Bonn [CGN]), Russia with 26,4\% share (Moscow-Sheremetyevo [SVO], Moscow-Domodedovo [DME], Saint Petersburg-Pulkovo [LED] and Vnukovo [VKO] airports), Denmark with a 3,4\% share (Copenhagen [CPH] airport), Finland with 3,3\% market share (Helsinki [HEL] airport), Norway with 1,6\% market share (Oslo [OSL] airport) and Sweden with 1,5\% share (Stockholm-Arlanda [ARN] and Gothenburg-Landvetter [GOT] airport).

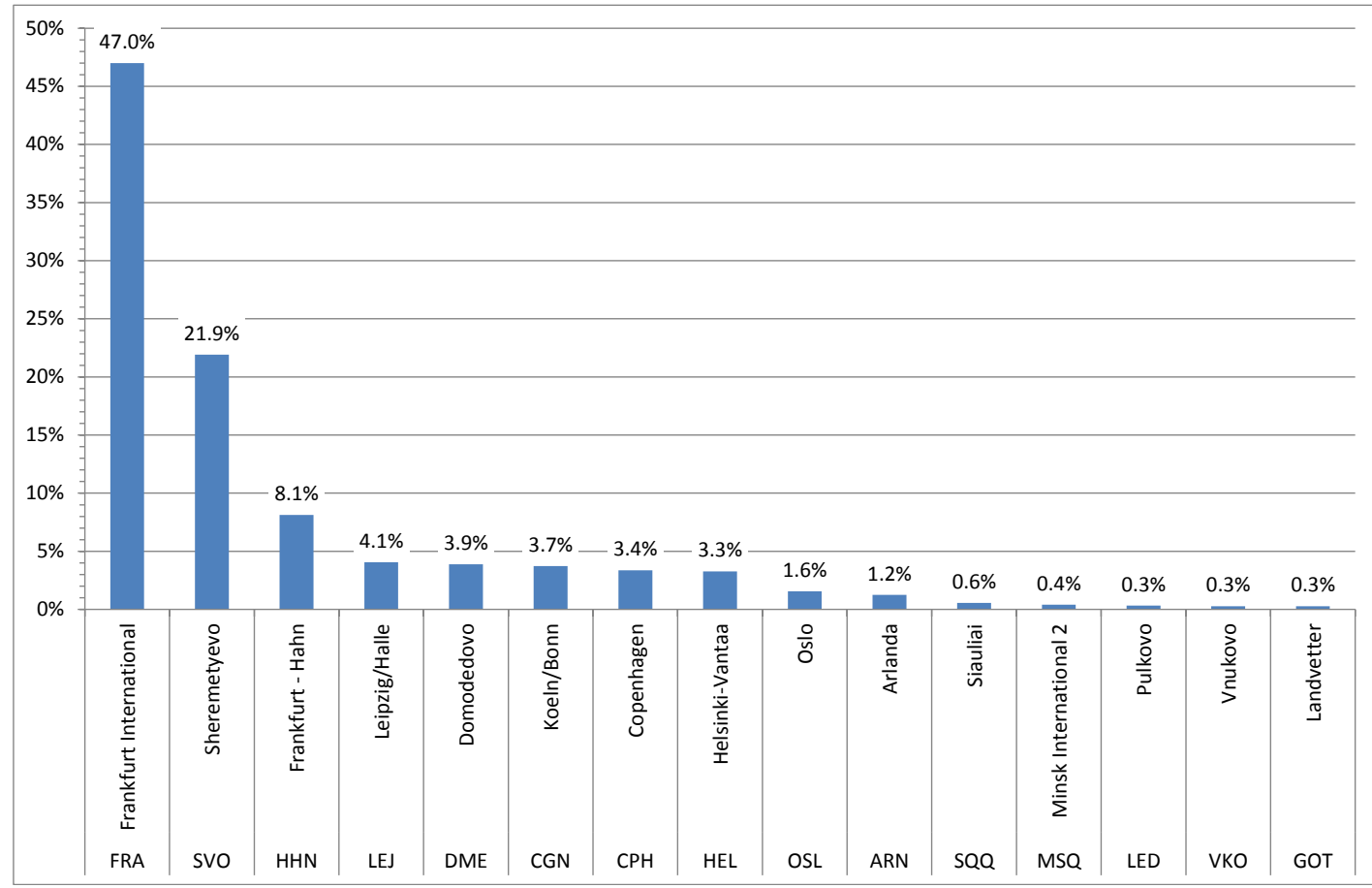

Figure 1. Distribution of Cargo-flights in the $\mathrm{BSR}^{5}$

According to breakdown to the average daily movement numbers there might be observed 127 average daily cargo flights at the defined sample of the BSR airports. This could be in indicator for a small and limited market, but with a very strong growth potential. If an average growth rate of $5 \%$ per annum can be maintained in the long-term in the BSR, then we may expect a doubling of the daily movements after 15 years and an increase by 164 daily movements (129\%) to a level of 291 daily movements by $2030 .{ }^{6}$ However, it might be stated that only big airports are taking advantages of the current air cargo business opportunities.

According to the "Baltic.AirCargo.Net" project data, the most regional airports in the Baltic Sea Region unfortunately act isolated and do not have a clear understanding of the current situation on the international air cargo market, they lack future perspectives and in some cases sustainable development plans. Trying to meet the market demand, the regional airports sometimes make huge and very often unjustified and unnecessary investments, e.g. improving airport infrastructure. However, the air cargo transport takes place not isolated but within a global net of value-added supply chains. Furthermore, it is not clear till now which elements of the Pan-Baltic cargo market could be managed as an alternative revenue yielding services for consolidated operation by air or what infrastructure is needed to provide the opportunity for an optimal economic mix of road-rail-air-sea transport?

Furthermore, to a large degree, air cargo traffic relies heavily on scheduled, frequent passenger services in hub-and-spoke system as well as in point-to-point traffic. Regional airports are presently suffering from a lack of scheduled uplift capacity. The volume currently transported by air in the Baltic Sea Region is almost entirely based on the occasional charter flights. However, the growth of the air

\footnotetext{
${ }^{5}$ Source: Economic Outlook for an Air Cargo market in the Baltic Sea Region, Baltic.AirCargo.Net Project, 2013

${ }^{6} \mathrm{cf}$. Economic Outlook for an Air Cargo market in the Baltic Sea Region, Baltic.AirCargo.Net Project, 2013
} 
cargo business is likely to be based not only on cargo charters, but to a larger extend on truck-based services for transit shipments.

Onward transportation by truck may occur on road feeder service, so called "flying trucks", where a real truck substitutes a flight. "Flying trucks" are having flight numbers etc., therefore they must be prioritized in many ways in the BSR transport policy.

\section{Interconnection between Accessibility of the Baltic Sea Region and the Air Cargo}

The role of the regional airports for the general accessibility as well multimodality is indispensable regional and national economies in the $\mathrm{EU}^{7}$

The accessibility of the Baltic Sea Region depends heavily on so called hub and spoke transport system. Most of the remote areas of the BSR could not reach the same accessibility (e.g. number of transport routes, destinations or frequencies; transport cost level, etc.) without hub and spoke model:

- Maritime: Container hubs like Hamburg offer overseas (intercontinental) connections and feeder traffic (e.g. Short Sea Shipping) is the spoke between the hub and the hinterland;

- Aviation: Aviation hubs like Copenhagen) offer intercontinental flight connections and feeder traffic (e.g. flying truck, Road Feeder Service) is the spoke between the hub and the hinterland.

Therefore, it can be stated that the Road Feeder Services along with the strong impact on the air cargo market also does heavily support the intercontinental passenger flights and the major aviation hubs of the Baltic Sea Region. Consequently it is very important to consider the fact that major aviation hubs of the BSR influence the accessibility of the BSR significantly and the economic viability of several intercontinental passenger flights strongly depends on the air cargo business, its efficiency and profitability.

The Finnair data might be a good example here: the Majority of Finnair's revenues generated by Europe - Asia traffic; whereas to be noted that the revenues coming from air cargo business represent ca. $20 \%$ of Asian revenues. As intercontinental passenger and cargo flights are strongly linked together, the so called "widebody" aircrafts performing the intercontinental flights carry significant part of the air cargo.

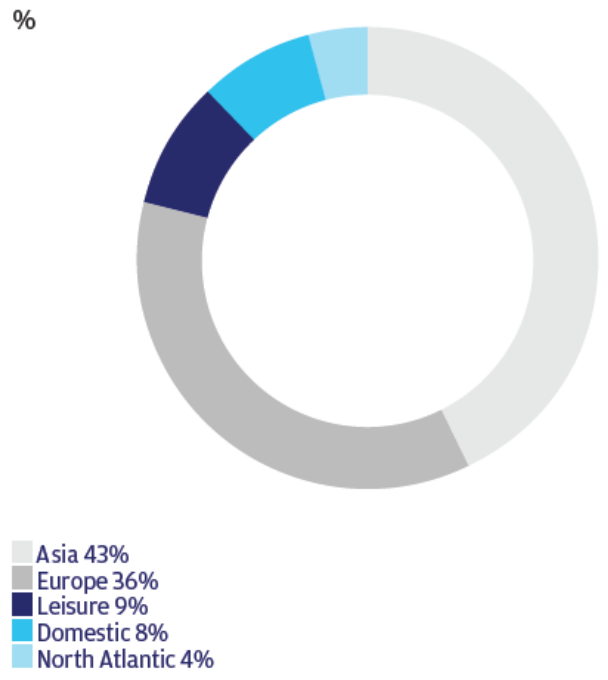

Figure 2. Distribution of revenues in scheduled traffic in Helsinki Airport (source: Finnair 2013)

According to Finnair data, the air cargo transported on scheduled flights (belly cargo) constitutes a significant proportion of the revenue from long-haul traffic; in 2013, belly cargo accounted for approximately $17 \%$ of total long-haul revenue. The overall load factor in Finnair's cargo traffic improved to $66 \%$, while the available tonne kilometres rose by $1,3 \%$. The new operating model strengthens air cargo demand in Finnair's Asian passenger flight network, as it also allows Finnair Cargo to offer faster cargo connections between Central Europe and Asia. ${ }^{8}$

\footnotetext{
${ }^{7} \mathrm{cf}$. European Parliament resolution of 10 May 2012 on the future of regional airports and air services in the EU (2011/2196(INI))

8 cf. Finnair Annual Report 2013, http://www.finnairgroup.com/linked/en/konserni/23162-Finnair_2013_EN_withlinks_v2.pdf
} 
Thus, it can be stated that the air cargo generates a significant part of revenues for the airlines that operate intercontinental flights. Therefore the economic viability of several intercontinental passenger flights is strongly dependent and directly relates to the air cargo business. The price level for the passengers directly depend on the utilization grade of the air cargo capacities of the "widebody" carriers. The results from the Baltic.AirCrago.Net project also confirm the statement that the major aviation hubs in the Baltic Sea Region generate significant part of their income from the air cargo business.

\section{Role of the Road Feeder Services in the Air Cargo}

There are different means of transportation that are being currently used to move goods within a fixed framework of a supply chain, business or legal regulations or under consideration of given characteristics and requirements. The air cargo transport may be generally regarded as external or internal transport. ${ }^{9}$

Under external transport it is meant the transfer of goods between single locations, e.g. between the shipper and the carrier. According to the given soft or hard infrastructural constrains, various modes of transportation are available: e.g. rail, road, see/ocean vessels, inland water carriers or aircraft. In the air cargo industry the traditionally assumed mode is considered to be aircraft. However, in practice the major part of supply and distribution of the officially declared air cargo are operated by special road vehicles.

Internal transportation defines the movement of the goods within a certain define infrastructure, i.e. airport. The transport from e.g. a terminal to a warehouse in an airport, whereas both locations belong to a single infrastructure unit.

A very good developed road-network infrastructure in Europe makes the development of alternative services to air transport possible via so called road feeder services. Due to the fact that majority of the pick up and delivery locations in Europe are rather at short or middle range distances, the delivery by truck, i.e. Road Feeder Service (RFS) often is the fastest, reliable and most cost efficient mode of transportation of the air cargo. Therefore the feeder service fulfilled by a truck provides many advantages, such as higher accessibility e.g. by pick up or delivery services, availability / simplicity in regard to executive units (trucks vs. aircrafts), certain flexibility in regard to an official time-schedule applied for the real air crafts e.g. in form of the given time slots and route. A traditional "flying truck" concept can be defined as a truck operating between two airports on so called Air Waybill (AWB) or air consignment note, which refers to a receipt that is issued by an international airline. It is very important to note that one truck might have several route numbers or flight numbers if it is carrying goods from more than one airline.

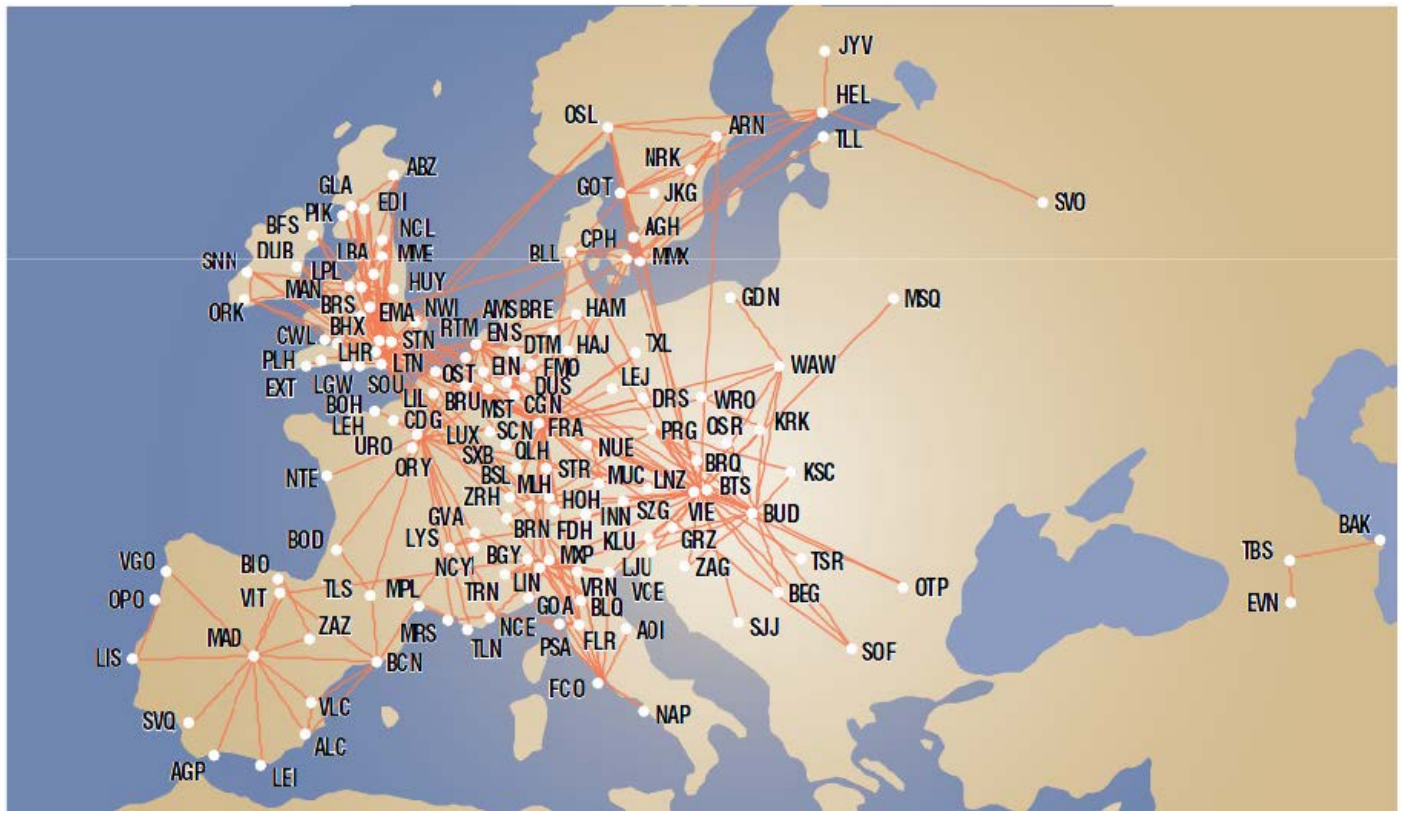

Figure 3. Scheduled truck-flight cargo service routes as of May 2007 (source: Boeing 2008)

\footnotetext{
${ }^{9}$ cf. Grandjot, Roessler, Roland, Air Cargo Guideline, 2007, 86-88
} 
Roughly summarized, the RFS or "flying trucks" from the point of view of documentation and security requirements processing are treated and handled exactly in the same way like real aircrafts, i.e. the "flying trucks" possess herewith exactly the same insurance as if the goods were transported by aircraft and on route number, they are fulfilling all custom and security regulations set by the relevant authorities as if the goods were really flying by air. ${ }^{10}$ The road feeder services mostly belong to the main executive leg in the transport chain and therefore provided and operated by the traditional airlines. Therefore the airlines possess an efficient alternative to deploy RFS for the shipments e.g. from a small or regional airport to a bigger (e.g. international) airport hub. RFS are also used for the air cargo consolidation in the hub/home airport of a given airline. The RFS same as a real aircraft do have a fixed time schedule, i.e. in comparison to traditional trucking services, the "flying trucks" dare not wait e.g. till the load capacity of a given truck is used to full extend, but it must leave the point of departure (e.g. Airport A) to a designated destination (e.g. Airport B) at exact time regardless its current load capacity.

The network of the operational Road Feeder Services in Europe has been considerably extended within last years and the road feeder concept has become to an essential part not only of the airfreight, but the whole logistics structural network. Although the concept is well known to air cargo professionals, it might be a bit unknown to representatives of other transport modes, regional actors and EU policy makers. Moreover the role of Road Feeder Services or "flying truck" concept and relationship to other transport modes as well as to other air cargo concepts is still underestimated and lacks behind its possibilities.

One flying truck can have several route numbers if it is carrying goods from more than one airline. The route numbers are set by local airline cargo manager, so there is no database to see the flying truck routes; and they are changing all the times. The Road Feeder Services also can happen while using the truck along with entire transport chain. The distances might vary from 100 up to 1000 kilometres and even more. Thus, while talking about air cargo transport services within Europe, normally professional mean delivery via RFS. ${ }^{11}$

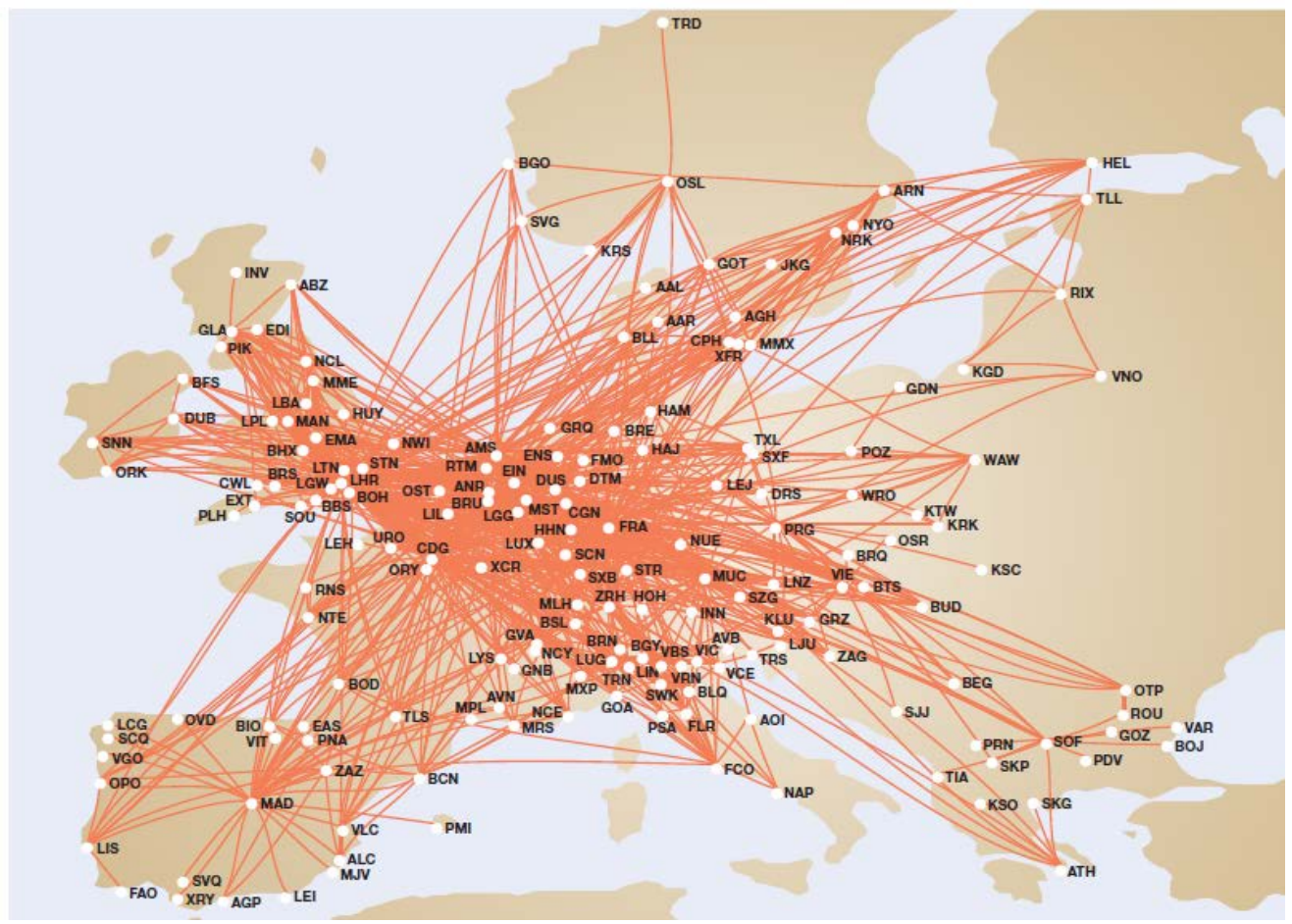

Figure 4. Scheduled truck-flight cargo service routes as of May 2010 (source: Boeing 2011)

The figures 3 and 4 demonstrate the rapid development of the RFS network in the air cargo business. However, according to the results of the Baltic.AirCargo.Net project the current EU transport strategies clearly underestimate its big role. Thus, it is of a vital importance to make "flying trucks" concept and its role in the international logistics network more known and understandable to a broader

\footnotetext{
${ }^{10}$ cf. Grandjot, Roessler, Roland, Air Cargo Guideline, 2007, 86-88

${ }^{11}$ Grandjot, Roessler, Roland, Air Cargo Guideline, 2007, 86-88
} 
community, for it shall be more efficiently adapted to the EU and BSR transport policies and regional development strategies.

Especially for small and regional airports that do not have international regular air flights and pure freight carriers, the recognition and implementation of the flying trucks concept might be of a special importance. Nowadays very few regional airports in the Baltic Sea Region utilize the Road Feeder Service. In many cases the flying trucks are operated only in the capital cities like Helsinki, Copenhagen, Stockholm (Arlanda) or major hub-airports like Hamburg. The project Baltic.Aircargo.Net is studying possibilities to utilize the concept also by the small and regional airports and thus support the economic viability of the regional airports in the BSR.

The Baltic.AirCargo.Net project has been focusing on remote airports and not on capital / major airports. The project has been trying to promote air cargo operations of remote airports through alternative concepts like "flying trucks", since might be almost impossible to utilize belly cargo concepts in the remote / regional airports. Also pure freighter concept is rather difficult even, if there is few success stories, for example Billund in Denmark and current plans of Parchim Airport to implement regular pure freighter line with China. Thus, the flying truck concept might be a very interesting and also realistic concept for remote airports when they are trying to access to the air cargo market. Preliminary interview results that have been carried out in the participating regions of the Baltic.AirCargo.Net project showed the regional airports have normally a sub-hub system to forwarders and integrators. Some airports are used as an interim-terminal where goods are collected for further transport to bigger hubs by road feeder services. The local SMEs are completely not involved in the air cargo mostly due to lack of knowledge and insight view of air cargo opportunities.

In the framework of the Baltic.AirCargo.Net Project three regional airports have been chosen as pilot sites for testing and demonstration, aiming also at promoting and implementation of the flying truck concept in their regions., i.e.:

- $\quad$ Tampere Airport in Finland;

- $\quad$ Linköping Airport in Sweden;

- Parchim Airport in Germany.

It has been recommended that the pilot sites interested in flying trucks concept implementation shall define their own detailed demonstration actions related to flying truck concept in the following frame:

- The sites shall familiarize themselves with the air cargo concepts, air cargo markets and roles of air cargo stakeholders. The planning of the demonstrations should be based on these facts of the air cargo.

- The roles of current air cargo concepts, cooperation and connections to other transport modes shall be identified. Each of these concepts has their advantages/disadvantages and thus the concepts are strong in different markets. What is the role of flying trucks, why, when and how it should be used?

- Identification of regional air cargo stakeholders - for example airport, airline (freighters, long-haul wide bodies, others) forwarders, ground handling, integrators, consignor, consignee - and their role in the logistics chain.

Although the concept of flying trucks is not so widely implemented and utilized by regional and small airports, e.g. in Finland only Helsinki is utilizing flying trucks concept and no one of regional airports is taking advantages of this. On the other hand, in Sweden quite many remote and regional airports have been already successfully implementing the flying truck concept:

- NYO, Skavsta

- $\quad$ NRK, Norrköping Kungsangen

- JKG, Jonköping

- $\quad$ AGH, Ängelholm-Helsingborg Airport

- $\quad$ MMX, Malmö Sturup

\section{Integration Opportunities of SMEs in the Road Feeder Services}

The finding of the Baltic.AirCargo.Net project, among other things showed that one of the most promising opportunities in terms of air transportation services that might be suitable for small and medium sized enterprises (thereafter: SMEs) or entrepreneurship is "Flying Truck" concept, which would enable providing differentiated, specialised qualitative services. The pure air cargo-forwarding sector 
implies big infrastructural investments, e.g. for the buying, leasing, maintaining of the machinery park, i.e. aircrafts. It is rather a naive assumption to believe that SMEs may possess the needed financial resources to start pure airfreight operations. On the other hand in regard to RFS, and according to the "Baltic.AirCargo.Net" project's results, among ca. 18 companies that offer airfreight transport services in Germany only few possess real aircrafts, i.e. the whole "fleet" of airfreight forwarders consists of normal trucks only and the majority of these transport companies that have been successfully operating on the air cargo transport market may be regarded as middle sized companies. And that were not the huge investments in the "hard-ware" infrastructure, i.e. aircrafts that allowed them to enter airfreight forwarding business, but rather strategically conceptual and "soft" changes.

Rather small and medium transport companies with a "fleet" ranging from 10 to 30 ordinary trucks qualified themselves for air cargo transport business. According to the results of the "Baltic.AirCargo.Net", the importance of the RFS is constantly growing nowadays, e.g. in 2012 the relative volume of air cargo transported by "flying trucks" in the biggest air cargo hub in the Baltic Sea Region - Copenhagen Airport is ca. 35\% from the total cargo volume.

By providing such road feeder services, the SMEs may benefit and gain an essential competitive advantage in the air cargo supply chain, due to their traditional flexibility in comparison to big companies. The provision of the air cargo by means of "flying trucks" may allow SMEs to take advantages of for integration with large air cargo forwarders in bigger logistic hubs, e.g. from Hamburg, Berlin. The road feeder services do not require intensive capital investments, fulfilment of the strict legal and security regulation framework and physical resources what would be a premise in case of providing air cargo services by means of an aircraft (airlines). By offering RFS from the air cargo hubs in bigger airport hubs, SMEs may be better involved into the air cargo market and the air cargo supplier network; as elaborated by Thomas and Barton, low technical capabilities of suppliers and limited physical resources (facilities, physical capital etc.) are likely to keep large air cargo forwarders and carriers from using in their supply networks and as part of their supply chains. ${ }^{12}$

\section{Summary and Outlooks}

It may be observed that during last decade, the regional airports in the Baltic Sea Region have improved point-to-point carriers operations due to general growth of low cost carriers in Europe and in offering their capacity to low cost carriers airlines. Therefore, the supply side of the air transport services within the EU has risen considerably; the competition among both airports and airlines has increased. The "good" consequences like lower fares, increased frequencies and more destinations for passengers and airfreight results also in lower revenues for the airports and airlines. Facing also the upcoming challenges in form of the cuts of the public aid, the regional airports must adopt their development strategies to able to operate on cost efficient and profitable basis. The air cargo business may offer to the regional airports a supplementary opportunity to the passenger traffic, thus making an airport more profitable and attractive for regional business structures.

Air cargo of the Baltic Sea Region is heavily concentrated on the airports, which have intercontinental passenger flights: significant part of the Baltic Sea Region air cargo is utilizing belly cargo concept and intercontinental passenger flights operated by wide body aircrafts. These airports are typically capital airports like Copenhagen (CPH), Stockholm (ARN) and Helsinki (HEL). Also the major part of the Baltic Sea Region freighter flights is operating to the same capital airports, which have the belly cargo flows.

The current results of Baltic.AirCargo.Net Project are pointing out that the Baltic Sea region transport policy should recognize and accept the importance of the Road Feeder Service or "Flying Truck" concept much stronger than it does today.

Aviation, i.e. both airports and airlines, are facing strong competition and the Baltic Sea Region should utilize possibilities that are being offered by Road Feeder Service in order to strengthen the economic viability of the aviation industry.

It can be generally noticed that within the Europe or the BSR the passengers are flying but the goods are being transported by flying trucks. It might be a disputable or provocative notice that the general and basic approach of the Short Sea Shipping corresponds with the concept of the Flying Trucks. The concept of the "Short Sea Shipping" has been introduced, discussed and promoted by relevant

\footnotetext{
12 cf. Beifert, A.; Maknyte, L.; Prause, G. SUSTAINABLE SUPPLY CHAIN MANAGEMENT ISSUES: CASE OF REGIONAL SMEs' INVOLVEMENT IN THE AIR CARGO. Journal of Security and Sustainability Issues, 2013, 3(2), 41 - 52.
} 
regional, national and international stakeholders. Should it be now recommendable to mention, promote, develop and implement efficient structures of the concept of Road Feeder Service?

Generally belly cargo concept might be impossible to implement by regional and remote airports since it is based on the intercontinental passenger flights. Furthermore, the freighter concept would be basically possible; however its implementation requires strong and consistent air cargo volume (e.g. 200 tons/week in and out) between the remote airport and some other region.

Thus, the Flying trucks concept might be at this time the only one realistic concept for remote and / or regional airports when they are trying to access to the air cargo market. In case of the acceptance of this hypothesis, the next questions for the regional airports that shall be analysed might be:

1. Role of the airport in the region;

2. What are the possible air cargo volumes, destinations in the catchment area of a given airport?

3. What are the possible "flying truck routes" for a given airport?

4. What are the goods-flows (annual volumes, frequencies) that might be potentially transported as air cargo within BSR? (described per segment: carried by freighters, carried by courier/express planes," carried by flying trucks")

5. What are the typical goods carried per route and direction, what is the balance of the flows?

Having fulfilled this analysis the regional airports might have a rough evaluation whether they can be an interesting feeder for some other major air cargo hub of the BSR region like Copenhagen, Helsinki or Stockholm (Arlanda) Airports. Furthermore, in the reference to the passenger traffic (network carriers, low cost, charter) and air cargo (RFS / flying trucks, freighters, mail / express) the following analysis shall be fulfilled:

1. transport forecast, objectives concerning volumes;

2. current capacities that are available in airport and its facilities;

3. future needs and possibilities of airport and its facilities, expansion plans.

Only after fulfilling above-mentioned evaluation it might be possible for regional airports to conduct a development strategy and a sustainable action plan involving among other things air cargo business opportunities.

\section{References}

1. Competition Policy Brief on the New State aid rules for a competitive aviation industry, Competition Directorate-General of the European Commission, Brussels 2014, ISBN 978-92-79-35541-7

2. Hans-Helmut Grandjot, Ingo Roessler, Ailine Roland, Air Cargo Guideline, Munich 2007, pp. 86-88, p. 271.

3. Bubalo, Branko, Economic Outlook for an Air Cargo Market in the Baltic Sea Region, Baltic.AirCargo.Net Project 2013.

4. Baltic Transport Outlook 2030. 2011. "Baltic Transport Outlook 2030 Executive Report - Annex II." http://www.baltictransportoutlook.eu/files/Executive_report_Annex2_TEN-T_Reviewmaps.pdf.

5. Doganis, R. S., and G. F. Thompson. 1975. "Airport Profitability And Managerial Effectiveness." The Manchester School 43 (4): 331-352. doi:10.1111/j.1467-9957.1975.tb01236.x.

6. Kim Irmov, and Hans Christian Stigaard, "To Identify the Current Air Cargo Set up and Flows in the Baltic Region, and to Identify the Possibilities to Improve These.”, Baltic.AirCargo.Net project 2013.

7. Manheim, L. M., Fundamentals of transport Systems Analysis, Volume 1: Basic concepts, 1979, p. 116.

8. European Parliament resolution of 10 May 2012 on the future of regional airports and air services in the EU. Brussels: European Commission (2011/2196(INI))

9. European Commission, 2005. Community Guidelines on Financing of Airports and Start-up aid to Airlines departing from Regional Airports. Brussels: European Commission (2005/C 312/ 01)

10. Beifert, A.; Maknyte, L.; Prause, G. SUSTAINABLE SUPPLY CHAIN MANAGEMENT ISSUES: CASE OF REGIONAL SMEs' INVOLVEMENT IN THE AIR CARGO. Journal of Security and Sustainability Issues, 2013, 3(2), 41 - 52.

Web sources:

11. Baltic.AirCargo.Net project: www.balticaircargo.net

12. Baltic Sea Region Programme 2007 - 2013, http://eu.baltic.net 
13. http://ec.europa.eu/economy_finance/economic_governance/sgp/index_en.htm

14. http://epp.eurostat.ec.europa.eu/statistics_explained/index.php/Freight_transport_statistics\#Air_ freight

15. Finnair Annual Report 2013, http://www.finnairgroup.com/linked/en/konserni/23162-

Finnair_2013_EN_withlinks_v2.pdf

16. http://epp.eurostat.ec.europa.eu/cache/ITY_OFFPUB/KS-RA-10-028/EN/KS-RA-10-028-EN.PDF

17. KS-RA-10-028-EN

18. http://ec.europa.eu/economy_finance/eu/forecasts/2013_winter_forecast_en.htm

19. EC $261 / 2004$ regulation establishing common rules on compensation and assistance to passengers in the event of denied boarding and of cancellation or long delay of flights 